\title{
GAMBARAN LIMBAH PADAT RUMAH PEMOTONGAN AYAM (RPA) TERHADAP TINGKAT KEPADATAN LALAT DI KELURAHAN BARA BARAYA TIMUR KOTA MAKASSAR Syamsuddin $S^{1}$ dan Sumarni ${ }^{2}$ \\ 1.2Poltekkes Kemenkes Makassar sumarnianni49@gmail.com
}

\begin{abstract}
Chicken slaughtering house is one of the livestock industry where live chickens are slaughtered and processed into chicken carcasses ready for consumption and also produce the remnants of slaughter that is not used anymore in the form of animal waste, solid waste and also the smell of sting that can invite flies and as a place to develop the breed flies. The aim of this study to know the description of solid waste Household slaughter (RPA) to the level of fly density in East Bara-Baraya Sub-district of Makassar City. This research type is descriptive observational that is doing the measurement of fly density. The number of samples in this study is 138 points, where the number of RPA as many as 23 and each taken 3 points with a total sampling technique. Results of research on filling in the questionnaire get eligible results of 12 RPA with 52\% percentage and who do not qualify 11 RPA with $48 \%$ percentage. And the result of measurement of the density of fly in the morning at point 1 average 4 tail, point 2 average 8 tail and point 3 average 5 tail while in measurement in afternoon get result at point 1 average 4 tail, point 2 on average 9 tail and point 3 on average 7 tail, where the level of flies density is high with the standard $\leq 2$ and $>2$ and does not meet the requirements according to Permenkes. 70 of 2016 . This research concludes that the density of flies in slaughterhouses is categorized as high with an average of 4-9 heads/blocks. Therefore the owner of the chicken slaughtering house should pay more attention to cleanliness so it does not become a breeding ground for flies. Keywords: Density of Flies, RPA, Solid Waste
\end{abstract}

\section{ABSTRAK}

Rumah Pemotongan ayam merupakan salah satu industri peternakan dimana dilakukan pemotongan ayam hidup dan mengolah menjadi karkas ayam siap konsumsi dan juga menghasilkan sisa-sisa penyembelihan yang tidak dipergunakan lagi yang berupa kotoran hewan, limbah padat dan juga bau menyengat yang dapat mengundang lalat dan sebagai tempat berkembang biaknya lalat. Penelitian ini bertujuan untuk mengetahui gambaran limbah padat rumah Pemotongan ayam (RPA) terhadap tingkat kepadatan lalat di Kelurahan Bara-Baraya Timur Kota Makassar. Jenis penelitian ini observasional deskriptif yaitu melakukan pengukuran kepadatan lalat. Adapun jumlah sampel dalam penelitian ini adalah sebanyak 138 titik, dimana jumlah RPA sebanyak 23 dan masingmasing diambil 3 titik dengan teknik total sampling. Hasil penelitian mengenai pengisian kuesioner di dapatkan hasil yang memenuhi syarat sebanyak 12 RPA dengan persentase $52 \%$ dan yang tidak memenuhi syarat 11 RPA dengan persentase $48 \%$. Dan hasil pengukuran kepadatan lalat di pagi hari pada titik 1 rata-rata 4 ekor, titik 2 rata-rata 8 ekor dan titik 3 rata-rata 5 ekor sedangkan pada pengukuran di sore hari di dapatkan hasil pada titik 1 rata-rata 4 ekor, titik 2 rata-rata 9 ekor dan titik 3 rata-rata 7 ekor, dimana tingkat kepadatan lalat yaitu tinggi dengan standar $\leq 2$ dan $>2$ serta tidak memenuhi syarat sesuai Permenkes No. 70 Tahun 2016. Kesimpulan dari penelitian ini adalah bahwa tingkat kepadatan lalat di rumah pemotongan ayam termasuk kategori tinggi dengan rata-rata 4-9 ekor/blok. Maka dari itu pemilik rumah pemotongan ayam harus lebih memperhatikan kebersihan sehingga tidak menjadi tempat perkembangbiakan lalat.

Kata Kunci : Kepadatan Lalat, RPA, Limbah Padat

\section{PENDAHULUAN}

Aktivitas pemotongan unggas membawa dampak pencemaran bagi lingkungan dan kesehatan masyrakat sekitar. Dampak pencemaran tersebut dilihat dari 3 aspek. Aspek yang pertama adalah aspek fisik, yaitu berupa limbah cair dan limbah padat hasil pemotongan unggas yang menimbulkan bau tak sedap. Aspek kedua adalah aspek kimia yaitu limbah yang dihasilkan dialirkan ke IPAL kemudian di alirkan kesungai yang berpotensi mencemari lingkungan dan sumber air. Aspek ketiga adalah aspek biologi, yaitu adanya timbulan sampah terutama limbah padat menjadi tempat perindukan lalat (Habib, 2013). Pengolahan limbah yang belum dikelola dengan baik oleh pengelola pemotongan ayam yang berada dekat dengan lingkungan masyarakat tentu saja berdampak pada masyarakat sekitar baik secara langsung maupun tidak. Untuk itu, Pemotongan unggas diarahkan menampung, mengolah limbahnya dan tidak membuangnya ke saluran umum (Ardiansyah, 2015 ).

Di Kota Makassar terdapat beberapa Rumah pemotongan ayam salah satunya di daerah Bara-Baraya. Berdasarkan data yang di peroleh dengan observasi yang lakukan di Kelurahan BaraBaraya Kota Makassar terdapat 23 usaha Rumah Pemotongan Ayam (RPA). Lokasi industri pemotongan hewan berada di tengah pemukiman warga. keberadaan industri pemotongan unggas ini akan menimbulkan masalah terhadap kualitas lingkungan permukiman, dan akan mempengaruhi kualitas air bersih, kualitas udara dan kualitas tanah. Limbah yang dihasilkan dari kegitan produksinya akan berpotensi menjadi tempat perkembang biakan berbagai vektor penyakit terutama lalat. Semakin meningkatnya populasi lalat tentunya akan berdampak pada kesehatan masyarakat sekitar 
Jurnal Sulolipu : Media Komunikasi Sivitas Akademika dan Masyarakat

Vol. 18 No 22018

e-issn : 2622-6960, p-issn : 0854-624X

berhubungan dengan penyakit yang disebabakan oleh vektor lalat.

Pentingnya pengukuran kepadatan lalat sebagai suatu alasan untuk mengetahui mengetahui tingkat kepadatannya. Berdasarka Keputusan Permenkes No. 70 Tahun 2016 menyajikan Standar Baku Mutu untuk lalat yang dikategorikan ke dalam SBM rendah dan tinggi bergantung pada lalat yang menempel di fly grill. Jika kurang atau sama dengan 2 ekor maka di kategorikan rendah atau baik. Sebaiknya jika lalat yang terperangkap lebih besar dari 2 ekor maka dapat dikatakan lingkungan industri tersebut kurang baik (Republik Indonesia, 2016). Pengendalian lalat harus di dasarkan atas pengamatan yang menyeluruh terhadap kondisi perumahan dan menentukan lokasi tempat perkembangbiakan lalat. Dengan perkataan lain dalam mengendalikan suatu serangga kita harus menganalisa terlebih dahulu sumber serangga,bagaimana populasi serangga tersebut meningkat, bagaimana derajat gangguan pada individu dan komonitas, dan peran serangga terhadap penularan penyakit ( Singgih, 2006 ).

\section{BAHAN DAN METODE}

\section{Lokasi Penelitian:}

Lokasi penelitian ini bertempat di rumah pemotongan ayam (RPA) Kelurahan BaraBaraya Timur Kota Makassar.

\section{Desain dan Variabel Penelitian}

Jenis penelitian yang digunakan dalam penelitian ini adalah observasional dengan pendekatan deskriptif yaitu melakukan pengukuran tingkat kepadatan lalat di Kelurahan Bara-Baraya Timur Kota Makassar.

Variabel Independent dalam penelitian ini adalah Timbulan, Pewadahan, Pengumpulan sedangkan Variabel Dependent yaitu Tingkat kepadatan lalat terhadap limbah padat RPA

\section{Populasi dan Sampel :}

Populasi dalam penelitian ini adalah seluruh rumah pemotongan ayam yaitu 23 RPA di Kelurahan Bara-Baraya Timur Kota Makassar.

Adapun teknik yang digunakan dalam penelitian ini adalah Teknik Total sampling dengan menggunakan kriteria dengan perhitungan jarak terbang lalat 400 meter. Adapun jumlah sampel dalam penelitian ini adalah sebanyak 138 titik sampel, dimana jumlah RPA sebanyak 23 dan masing-masing diambil 3 titik pengukuran (sekitar rumah pemotongan ayam, tempat pembuangan limbah padat, dan tempat pemotongan) dalam 1 rumah pemotongan ayam dengan frekuenasi waktu pengukuran kepadatan lalat pagi dan sore hari.

4. Pengumpulan data

Data primer diperoleh dari hasil pengukuran kepadatan lalat dan hasil pengamatan. Data sekunder diperoleh dari hasil penelusuran perpustakaan berupa bukubuku yang berkaitan dengan penelitian, hasil penelitian sebelumnya serta internet dan media informasi lainnya.

5. Analisa Data (Jika memakai program statistic, tuliskan uji utama apa yang digunakan)

Hasil pengamatan dan pengukuran lapangan menggunakan uji statistik parametrik dengan uji T (T-test) untuk mengetahui tingkat kepadatan lalat, kemudian disajikan dalam bentuk tabel. Hasil dari setiap pengukuran tingkat kepadatan lalat di bandingkan dengan standar yang ditetapkan.

HASIL

Pada hasil dari pengukuran Pengaruh Limbah Padat Rumah Pemotongan Ayam (RPA) terhadap Tingkat Kepadatan Lalat, suhu dan kelembaban pada lokasi pemotongan ayam yang dilaksanakan pada tanggal $10-11$ Mei 2018. Adapun Hasil yang diperoleh sebagai berikut :

1. Pengukuran Tingkat Kepadatan Lalat di Rumah Pemotongan Ayam

Hasil pengukuran pengaruh limbah padat terhadap tingkat kepadatan lalat di kelurahan Bara-Barayya Timur Kota Makassar dapat dilihat pada tabel berikut:

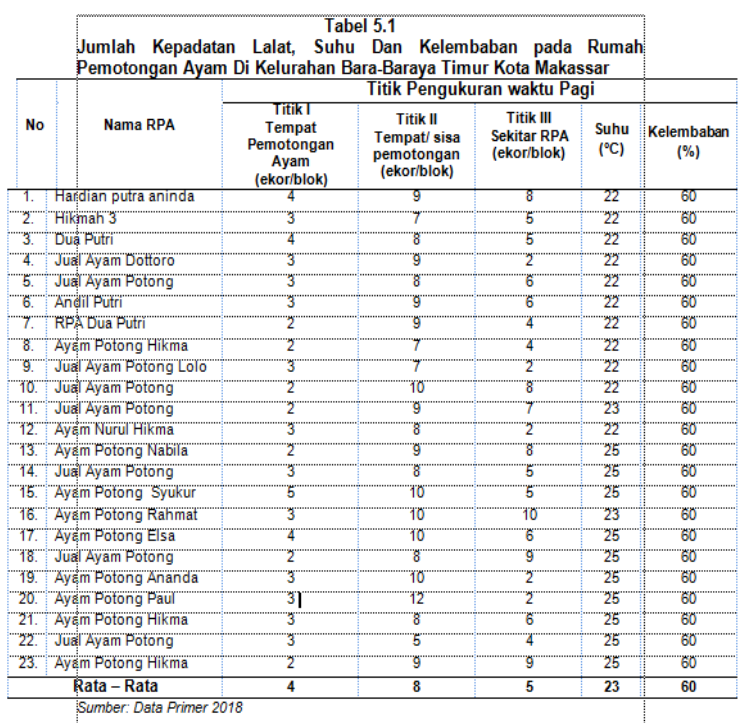

Dari Tabel 1 dapat dilihat bahwa hasil pengukuran pagi hari menunjukkan jumlah Kepadatan Lalat, Suhu Dan Kelembaban pada Rumah Pemotongan 
Jurnal Sulolipu : Media Komunikasi Sivitas Akademika dan Masyarakat

Vol. 18 No 22018

e-issn : 2622-6960, p-issn : 0854-624X

Ayam Di Kelurahan Bara-Barayya Timur terdapat 3 titik yaitu pada titik I bagian pemotongan ayam dengan kepadatan rata-rata 4 ekor/blok grill, titik II bagian tempat pembuangan sisa pemotongan dengan kepadatan rata-rata 8 ekor/blok grill, dan titik III sekitar rumah pemotongan ayam dengan kepadatan rata-rata 5 ekor/blok grill. Adapun ratarata pada hasil pengukuran suhu yaitu $23^{\circ} \mathrm{C}$ dan kelembaban $60 \%$.

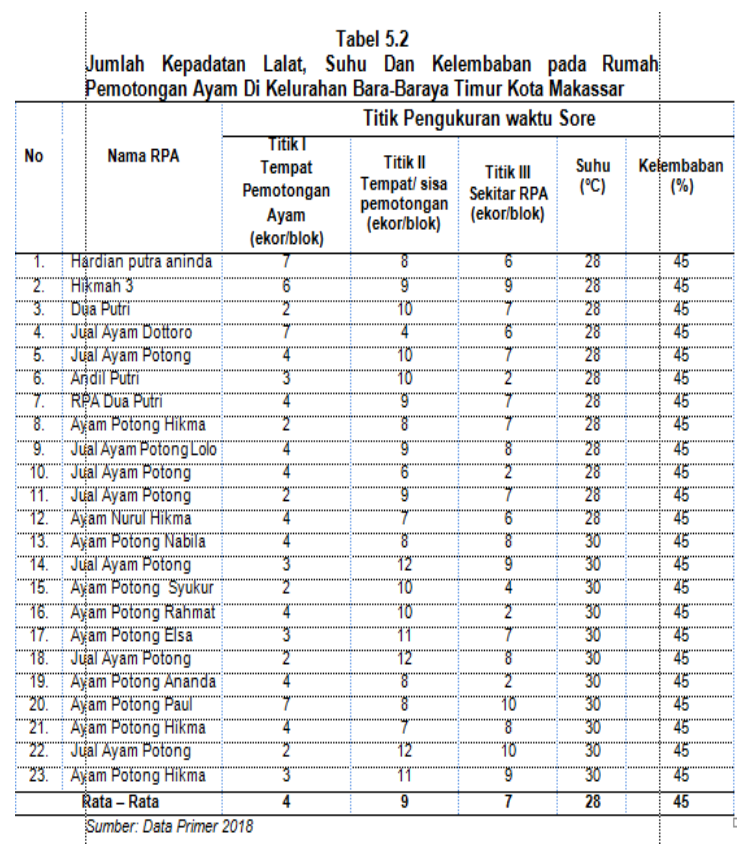

Dari Tabel 2 dapat dilihat bahwa hasil pengukuran sore hari menunjukkan jumlah Kepadatan Lalat,Suhu Dan Kelembaban pada Rumah Pemotongan Ayam Di Kelurahan BaraBarayya Timur Kota Makassar terdapat 3 titik yaitu pada titik I bagian pemotongan ayam dengan kepadatan rata-rata 4 ekor/blok grill, titik II bagian tempat pembuangan sisa pemotongan dengan kepadatan rata-rata 9 ekor/blok grill, dan titik III sekitar rumah pemotongan ayam dengan kepadatan rata-rata 7 ekor/blok grill. Adapun rata-rata pada hasil pengukuran suhu yaitu $28^{\circ} \mathrm{C}$ dan kelembaban yaitu $45 \%$

\section{Distribusi kondisi Sarana Sanitasi Rumah Pemotongan Ayam di Kelurahan Bara-Baraya Timur Kota Makassar}

Hasil observasi ketersediaan sarana rumah pemotongan di Kelurahan Bara-Baraya Timur Kota Makassar dapat dilihat pada tabel berikut:
Tabel 3

kondisi Sarana Rumah Pemotongan Ayam di Kelurahan Bara-Baraya Timur Kota Makassar Memenuhi syarat

Tidak Memenuhi

Syarat

RPA Total Persentase Total Persentase

$\begin{array}{lllll}23 & 12 & 52 \% & 11 & 48 \%\end{array}$

Sumber: Data Primer 2018

Berdasarkan Tabel 5.3 diketahui bahwa hasil observasi yang dilakukan terdapat jumlah rumah pemotongan ayam sebanyak 23 RPA, di dapatkan hasil yang memenuhi syarat sebanyak 12 RPA dengan persentase $52 \%$ dan yang tidak memenuhi syarat 11 RPA dengan persentase $48 \%$.

Setelah dilakukan $\mathrm{Uji} T$ dengan menggunakan aplikasi SPSS versi 24.00 dan nilai alpha yang digunakan yaitu $\alpha=0,05$ maka diperoleh hasil yaitu nilai $p=0,000$. Berdasarkan hal tersebut dimana $p<$ $\alpha$, maka dapat dinyatakan bahwa $\mathrm{HO}$ ditolak. Hal ini berarti ada pengaruh antara limbah padat rumah pemotongan ayam dengan tingkat kepadatan lalat

\section{PEMBAHASAN}

Berdasarkan hasil penelitian yang dilakukan yaitu "Gambaran Limbah Padat Terhadap Tingkat Kepadatan Lalat di Kelurahan Bara-Baraya Timur Kota Makassar, maka dapat di uraikan sebagai berikut:

1. Tingkat Kepadatan Lalat di Rumah Pemotongan Ayam (RPA), Suhu dan Kelembaban di Kel. Bara-Baraya Timur Kota Makassar

Berdasarkan hasil penelitian yang dilakukan pada saat melakukan penelitian untuk hasil dapat pengukuran pagi dan sore hari menunjukkan jumlah Kepadatan Lalat, Suhu Dan Kelembaban pada Rumah Pemotongan Ayam Di Kelurahan Bara-Baraya Timur Kota Makassar terdapat 3 titik yaitu Tingkat kepadatan lalat yang didapatkan yaitu tinggi karena hasil pengukuran diperoleh dengan rata-rata 4-9 ekor/blok, Serta tidak memenuhi syarat sesuai Permenkes No. 70 Tahun 2016. Adapun rata-rata pada hasil pengukuran suhu yaitu $28^{\circ} \mathrm{C}$ dimana lalat pada suhu tersebut dapat beraktifitas secara optimum, karena temperatur yang disukai lalat berkisat antara $21^{\circ} \mathrm{C}-32^{\circ} \mathrm{C}$. dan kelembaban yaitu $45 \%$ karena pada temperature tersebut lalat beraktifitas secara optimum. 
Jurnal Sulolipu : Media Komunikasi Sivitas Akademika dan Masyarakat

Vol. 18 No 22018

e-issn : 2622-6960, p-issn : 0854-624X

Tingginya tingkat kepadatan lalat pada rumah pemotongan ayam sangat berpengaruh terhadap limbah padat (bulu, sisa usus/ jeroan, potongan kepala dan tulang) yang dihasilkan rumah pemotongan ayam. Di lilihat dari pola hidupnya bahwa lalat sangat menyukai tempattempat yang kotor dan limbah padat yang mudah membusuk atau menimbulkan bau tidak sedap sehingga menjadi daya tarik berkembang biaknya lalat. Dengan terdapatnya banyak lalat yang berterbangan di rumah pemotongan ayam dan larva lalat yang berkembangbiak di penampungan pembuangan limbah padat bekas pemotongan ayam, dengan melihat kondisi tempat pembuangan tersebut yang tidak memiliki penutup dan kedap air sehingga bau yang ditimbulkan mencemari udara dan menjadi perkembangbiakan lalat pada rumah pemotongan ayam (RPA) di Kelurahan BaraBaraya Timur Kota Makassar. Pada pemukiman di sekitar rumah pemotongan ayam di BaraBaraya Timur juga tidak terlepas dari hal tersebut. Keberadaan lalat tersebut dikarenakan adanya faktor yang mendukung kelangsungan hidup bagi lalat. Faktor-faktor tersebut antara lain jarak pemukiman yang berdekatan dengan rumah pemotongan ayam (RPA) membuat tingginya tingkat kepadatan lalat dan sanitasi lingkungan di rumah pemotongan ayam yang kurang memadai dan keberadaan sumber makanan bagi lalat yang mendukung perkembangbiakan lalat sehingga di Kelurahan Bara-Baraya Timur Kota Makassar dikatakan tingkat kepadatan lalatnya tinggi.

Penyebaran lalat sangat dipengaruhi oleh suhu dan kelembaban, untuk istirahat lalat memerlukan suhu sekitar $21^{\circ}-32^{\circ} \mathrm{C}$, kelembaban $90 \%$. Sehingga menyebabkan jumlah lalat meningkat dan sangat aktif untuk mencari makan. Lalat beraktifitas optimal pada pada kelembaban antara $90 \%$ sedangkan kelembaban yang ada pada rumah pemotongan ayam ratarata $45 \%$ - $60 \%$ dimana tingkat kelembaban ini sangat mendukung siklus hidup lalat karena lalat menyukai tempat - tempat yang lembab. Lalat mulai aktif beraktifitas pada temperatur $15{ }^{\circ} \mathrm{C}$ dan aktifitas optimumnya pada temperatur $21^{\circ} \mathrm{C}$, lalat memerlukan suhu sekitar $35-40 \stackrel{\circ}{\circ} \mathrm{C}$ untuk beristirahat, dan pada temperatur di bawah 10 ${ }^{\circ} \mathrm{C}$ lalat tidak aktif dan di atas $45{ }^{\circ} \mathrm{C}$ terjadi kematian pada lalat. Kelembaban erat hubungannya dengan temperatur setempat. Kelembaban berbanding terbalik dengan temperatur. Jumlah lalat pada musim hujan lebih banyak dari pada musim panas. Lalat sangat sensitif terhadap angin yang kencang, sehingga kurang aktif untuk keluar mencari makanan pada waktu kecepatan angin tinggi.

Sejalan dengan penelitian Habib Alfa Eni Kurniawan (2013) tentang studi deskriptif tingkat kepadatan lalat dipermukiman sekitar rumah pemotongan unggas (RPU) Penggaron Kelurahan Penggaron Kudul Kecematan Pedurungan Kota Semarang di dapatkan hasil tingkat kepadatan lalat di permukiman sekitar RPU Penggaron termasuk kategori Rendah (38\%). Pemukiman di zona I $(0-\leq 1000 \mathrm{~m})$ terdapat tingkat kepadatan lalat kategori tinggi sebesar $65,6 \%$, sedangkan pemukiman di zona II $(>1000-\leq 2000 \mathrm{~m})$ terdapat tingkat kepadatan lalat kategori tinggi sebesar $11,6 \%$. Pemukiman yang tidak memenuhi syarat sanitasi sarana pemukiman terdapat tingkat kepadatan lalat kategori tinggi sebesar $36,8 \%$, sedangkan pemukiman yang memenuhi syarat sanitasi sarana pemukiman terdapat tingkat kepadatan lalat kategori tinggi $0 \%$. Pemukiman yang memiliki ternak terdapat tingkat kepadatan lalat kategori tinggi sebesar $31,1 \%$ sedangkan pemukiman yang tidak memiliki ternak tingkat kepadatan lalat kategori tinggi sebesar $29,8 \%$. Tingginya tingkat kepadatan lalat dirumah penduduk di wilayah Penggaron Kidul, di duga ada kaitannya dengan jarak pemukiman penduduk dengan rumah potong unggas (RPU) Penggaron yang hanya berjarak kurang dari 100 $\mathrm{m}$. Selain jarak tersebut di duga ada kaitannya dengan sanitasi sarana pemukiman dan kepemilikan ternak di wilayah tersebut.

\section{Distribusi kondisi Sarana Rumah Pemotongan Ayam di Kelurahan Bara-Baraya Timur Kota Makassar}

Berdasarkan Tabel 5.3 Hasil observasi yang dilakukan, sebanyak 23 RPA dimana hasil yang memenuhi syarat sebanyak 12 RPA dengan persentase $52 \%$ dan yang tidak memenuhi syarat 11 RPA dengan persentase $48 \%$. Dimana diketahui bahwa sanitasi lingkungan di Rumah Pemotongan Ayam (RPA) perlu diperhatikan oleh pihak pengelola, serta kesadaran pemilik RPA untuk membuang sampah pada tempatnya dan menjaga kebersihan dilingkungan sekitar RPA tersebut karena membuang limbah secara sembarangan seperti sisa buangan dari suatu kegiatan usaha pemotongan ayam meliputi limbah padat (bulu, sisa usus/jeroan, potongan kepala dan tulang) yang berakibat lingkungan menjadi kotor sehingga dapat mengundang lalat, sedangkan kondisi sanitasi lingkungan yang baik akan mengurangi kepadatan lalat. 
Jurnal Sulolipu : Media Komunikasi Sivitas Akademika dan Masyarakat

Vol. 18 No 22018

e-issn : 2622-6960, p-issn : 0854-624X

Berdasarkan hasil pengukuran kepadatan lalat pada titik I, II, dan III terdapat perbedaan kepadatan lalat hal ini depengaruhi karena pada titik I tempat pemotongan ayam dimana dilakukan aktivitas hanya pemotongan ayam dan aktivitas pekerja selalu bergerak sehingga hasil kepadatan lalat berkurang. Pada titik II tempat/sisa pemotongan dimana disini terdapat limbah padat seperti bulu, sisa usus/jeroan, potongan kepala dan tulang sehingga terjadi kepadatan lalat pada tempat tersebut. Pada titik III sekitar rumah pemotongan ayam hanya terdapat limbah cair dari aktivitas pencucian ayam dan dimana terdapat aktivitas manusia dan kendaraan lalu lalang sehingga kepadatan lalat berkurang. Pada pengukuran pagi aktivitas pemotongan ayam banyak dibandingkan pada sore hari sehingga limbah padat yang dihasilkan pada pagi hari belum terkumpul dan masih berserakan namun belum menimbulkan bau karena kondisi fisiknya masih segar. Sedangkan pada sore hari aktivitas pemotongan ayam mulai berkurang namun kondisi fisik limbah yang dihasilkan sudah menimbulkan bau sehingga terjadi kepadatan lalat pada sore tinggi dibanding pada sore hari.

Limbah padat terhadap tingkat kepadatan lalat di rumah pemotongan ayam (RPA) sangat erat kaitannya dengan kondisi sanitasi yang ada di rumah pemotongan ayam yang memiliki peran sebagai pemicu timbulnya kepadatan lalat apabila tidak menerapkan upaya kesehatan lingkungan dalam hal ini limbah padat yang kurang baik pengelolaannya tentu saja berdampak pada kesehatan masyarakat sekitar. Kondisi tempat sampah yang digunakan pemilik rumah pemotongan ayam rata-rata tidak memiliki penutup dan kedap air, akan tetapi pengangkutan dan pembersihan dilakukan tiap hari.

Pengelolaan limbah yang kurang baik akan berakibat buruk terhadap lingkungan dan kesehatan masyarakat. Beberapa akibat buruk yang ditimbulkannya adalah terhadap lingkungan, limbah dapat menimbulkan bau yang tidak sedap, sarang berkembang biaknya vektor seperti lalat dan lain-lain apa bila tidak dikelola dengan baik dan terhadap manusia, limbah padat yang tidak dikelola dengan baik dapat membahayakan kesehatan manusia (Ardiansyah, 2015).

Lalat merupakan serangga yang dapat menimbulkan gangguan atau menularkan penyakit pada manusia. Sumber makanan lalat sangat bervariasia, mulai dari kotoran hewan/ manusia, makanan manusia, dan sebagai parasit di dalam atau luar tubuh hewan. Melimpahnya populasi lalat dapat mengganggu ketentraman manusia dan hewan karena gigitannya atau peranannya yang dapat menyebarkan berbagai jenis penyakit seperti: myasis pada luka terbuka, colera, disentri amoeba, disentri bacciller, leishmahiasis, dan thypus fever. Penyebaran penyakit dibawa oleh lalat yang berasal dari sampah, kotoran manusia/ hewan terutama bulubulu badannya, kaki dan bagian tubuh yang lain dari lalat dan bila lalat hinggap kemakanan manusia maka kotoran tersebut akan mencemari makanan yang akan dimakan oleh manusia sehingga timbul terjadinya penyakit.

Lalat yang berada di sekitar hunian manusia antara lain adalah lalat rumah, lalat hijau, dan lalat daging. Umumnya lalat ini berkembangbiak pada habitat di luar hunian manusia yang telah membusuk dan penuh dengan bakteri dan organisme patogen lainnya, seperti vegetasi yang membusuk, kotoran hewan, dan sampah atau limbah padat.

Lalat adalah insekta yang mengalami metamorfosa yang sempurna, dengan stadium telur, larva, kepompong dan stadium dewasa. Perkembangan lalat memerlukan waktu antara 7-22 hari. Pada siang hari lalat bergerombol atau berkumpul dan berkembang biak di sekitar sumber makanannya. Penyebaran lalat sangat dipengaruhi oleh cahaya, temperatur, kelembaban. Untuk istirahat lalat memerlukan suhu sekitar $35^{\circ}-40^{\circ} \mathrm{C}$, kelembaban $90 \%$. Aktifitas terhenti pada temperatur $<15^{\circ} \mathrm{C}$.

Jarak terbang lalat sangat tergantung pada adanya makanan yang tersedia. Jarak terbang efektif adalah 450-900 meter. Lalat tidak kuat terbang menantang arah angin, tetapi sebaliknya lalat akan terbang mencapai $1 \mathrm{~km}$. Lama kehidupan lalat sangat tergantung pada makanan, air dan temperature. Pada musim panas berkisar antara 2-4 minggu, sedangkan pada musim dingin bisa mencapai 70 hari.

Beberapa cara pengendalian yang dapat dilakukan adalah sebagai berikut:

\section{a. Pengendalian dengan hygiene dan sanitasi lingkungan}

Pengendalian lalat dengan sanitasi lingkungan sebenarnya adalah untuk mengurangi atau menghilangkan tempattempat perindukan lalat dengan mengurangi sumber yang memungkinkan bagi alat untuk berkembang baik (Permenkes no. 50 tahun 2017). Adapun upaya yang dapat dilakukan yaitu sebagai berikut: 
1) Menjaga dan memelihara kebersihan lingkungan perumahan, TTU seperti pasar, rumah sakit, bioskop dan lain-lain.

2) Pengaturan sistem pengumpulan sampah pada tempat-tempat pembuangan sampah sementara dengan cara baik. Melakukan pembuangan sampah yang memenuhi syarat kesehatan yaitu dengan cara pembuangan sampah pada tempatnya dan tempat sampah yang tertutup. Perlindungan makanan, perkakas dan manusia kontak dengan lalat terutama dalam rumah dapat dipasang kassa pada pintu jendela, setiap lubang pada dinding lantai tertutup, perlu juga untuk toko, pasar dan lain-lain.

3) Meningkatkan pendidikan dan peran serta masyarakat dalam program sanitasi lingkungan dengan kerja sama antara kelompok masyarakat dan pengumpulan serta pembuangan sampah yan terorganisir.

b. Pengendalian non kimiawi

Cara pengendalian non-kimia untuk lalat dewasa tersebut dari mulai alat pengusir dan jebakan lalat yang sangat sederhana seperti kertas perekat lalat, sampai dengan yang sangat canggih seperti perangkap lampu (light trap) yang dapat membunuh lalat dewasa dengan aliran listrik

Lalat dapat disingkirkan dari permukiman. $\mathrm{Di}$ tempat pengolahan makanan, tirai udara merupakan alat yang sangat efektif. Pemasangan kasa anti serangga pada jendela, pintu dan tempattempat masuk merupakan cara yang banyak dipakai. Penghilangan bau yang menarik bagi lalat melalui ventilasi yang baik, pembersihan berbagai peralatan pengolahan makanan segera setelah dipakai, dan berbagai praktek kebersihan yang baik dan terus menerus merupakan cara yang paling efektif mencegah meningkatnya populasi lalat.

c. Pengendalian kimiawi atau insektisida

pengendalian non-kimiawi seperti upaya hygiene sanitasi, insektisda dapat memegang peranan penting dalam pengendalian lalat. Secara praktis insektisida banyak digunakan untuk mengendalikan lalat dewasa seperti insektisda golongan organofosfor, karbamat dan berbagai jenis piretroid sintetik.

Penggunaan insektisda dalam pengendalian lalat bisa meliputi pembunuhan larva (larvasida), penolakan lalat dewasa (repelan), atau pembunuhan lalat dewasa dengan cara penyemprotan residual pada permukaan, penyemprotan ruangan atau pemasangan umpan. Seringkali juga dalam bentuk kombinasi cara-cara tersebut:

1) Larvasida

Meskipun larvasida yang digunakan untuk dalam bentuk formula umpan dan serbuk, pendekatan yang umum dipakai adalah penyemprotan permukaan dengan bahan dasar air yang dapat membasahi larva dan tempat-tempat makanan lalat.

2) Repelen Ialat

Formulasi untuk repelen ini ada dalam bentuk cair dioleskan dan aerosol. Kebanyakan formula ini mengandung piretrin alami dengan kosentrasi rendah yang digabung dengan bahan kimia khusus agar efek repelennya meningkat seperti dietil toluamid dan $\mathrm{N}$-oktil bisiklohepten dikarboksimida. Formulasi ini dapat melindungi diri dari lalat selama beberapa jam.

3) Penyemprotan permukaan

Keefektifan penyemprotan ini dalam pengendalian lalat sangat tergantung pada permukaan tempat yang akan disemprot, misalnya penyemprotan harus dilakukan pada tempat-tempat yang sering di datangi oleh lalat. Seharusnya dilakukan diskusi dengan klien saat inspeksi dilakukan, terutama tentang sifat dan keberadaan lalat, serta kebiasaan istirahat lalat di sekitar bangunan.

4) Penyemprotan ruangan

Umumnya masalah lalat dipermukiman diatasi dengan menggunakan bentuk formulasi aerosol bertekanan rendah. Umunya formulasi ini terdiri atas piretroid sinetik karena relatif aman dan memberikan efek kelumpuhan dan membunuh yang cepat

5) Pengumpanan (Baiting)

Penggunaan umpan untuk mengendalikan lalat dapat dilakukan tetapi dalam jangka pendek. Bentuk umpan siap pakai yang terdapat di pasaran biasanya digunaskan dengan cara ditaburkan disekitar tempat lalat berkerumun, dan hasilnya cukup efektif. Namun yang perlu diperhatikan adalah adanya kompetisi bau yang dapat menarik lalat datang ketempat makanan lain dapat menurunkan daya efektifitas umpan lalat 
Jurnal Sulolipu : Media Komunikasi Sivitas Akademika dan Masyarakat

Vol. 18 No 22018

e-issn : 2622-6960, p-issn : 0854-624X

\section{PENUTUP}

\section{KESIMPULAN}

a. Limbah padat terhadap tingkat kepadatan lalat di rumah pemotongan ayam (RPA) erat kaitannya dengan kondisi sanitasi yang ada dan sebagai pemicu timbulnya kepadatan lalat dan tempat berkembang biaknya.

b. Pada pengukuran pagi dan sore hari dengan 3 titik didapatkan hasil tingkat kepadatan lalat tinggi karena hasil yang diperoleh rata-rata 4-9 ekor/blok. Serta tidak memenuhi syarat sesuai Permenkes No. 70 Tahun 2016.

\section{SARAN}

a. Sebaiknya di lokasi rumah pemotongan ayam (RPA) lebih memperhatikan kebersihan sehingga lalat tidak berkembang biak pada rumah pemotongan ayam.

b. Sebaiknya pemerintah setempat melakukan penanganan limbah padat pada rumah pemotongan ayam (RPA).

c. Sebaiknya pemerintah setempat memberikan sosialisasi kepada masyarakat terhadap tingkat kepedatan lalat di rumah pemotongan ayam, sehingga pentingnya mejaga kebersihan lingkungan dan menghindari penyakit berbasis lingkungan.

\section{DAFTAR PUSTAKA}

Ardiansyah. 2015. Adaptasi Masyarakat Terhadap Kesehatan Keberadaan Rumah Potong Ayam Di Kelurahan Bara-Barayya Timur Kecematan Makassar Kota Makassar. Makassar : Universitas Hasanuddin. (Skripsi tidak diterbitkan)

Bambang Agus Murtidjo. 2013. Pemotongan Dan Penanganan Daging Ayam. Yogyakarta : Kanisius.

Chasan S Kusnadi. 2004. Pengendalian Vektor dan Binatang Penganggu. Makassar : Politeknik Kesehatan Makassar Jurusan Kesehatan Lingkungan.

Dantje T Sembel. 2009. Entomologi Kedokteran. Yogyakarta : Andi Offset.

Devi Nuraini Santi. 2013. Manajemen Pengendalian Lalat. (Online). http://respository.usu.ac.id/bitstream/123456789/3497/1/fk-Devi.pdf, Diakses 24 Desember 2017

Dewi Susanna dan Terang Uli J Sembiring. 2011. Entomologi Kesehatan. Jakarta : Universitas Indonesia (Ui-Press).

Eko De Arragosta. 2017. Studi Tingkat Kepadatan Lalat di Permukiman Sekitar Rumah Potong Ayam di Kelurahan Bara-Barayya Utara Kota Makassar. Makassar : AKL Poltekkes Makassar. (KTI tidak diterbitkan)

Ferani $\quad 2014 . \quad$ Macam Macam Limbah. $\quad$ (Online). https://feranianggraini23.wordpress.com/2014/09/10/macam-macam-limbah/. diakses tanggal 28 Desember 2017.

Habib Alfa Eni Kurniawan. 2013. Studi Deskriftif Tingkat Kepadatan Lalat Di Permukiman Sekitar Rumah Pemotongan Unggas (RPU) Penggaron Kelurahan Penggaron Kudul Kecematan Pedurungan Kota Semarang. Unnes Journal of Public Healt volume 2 (4) : 1-13. (Online). http://ejournal.Unnes.ac.id. Diakses 13 Desember 2017.

Iman Rahayu, dkk. 2011. Panduan Lengkap Ayam. Bogor : Penebar Swadaya.

Intan Ahmad, dkk. 2015. Resistensi Lalat Rumah Musca Domestica Linnaeus (Diptera Muscidae) Dari Empat Kota Di Indonesia Terhadap Premetrin Dan Propoksur. Jurnal Entomologi Indonesia Vol 12 No 3, 123-128.(Online). http://jurnal.pei-pusat.org. Diakses 28 Januari 2018

Irvan Galantino, dkk. 2015. Analisis Kualitas Pelayanan Terhadap Kepuasan Konsumen Pembeli Karkas Boiler di Rumah Potong Ayam (RPA) Kelurahan Kampung Mandar Kabupaten Bayuwangi. Fakultas Peternakan UB volume (1) : 47-54. (Online). http://Journal.jip.vb.ac.id. Diakses 28 Desember 2017

Kuncoro Sejati. 2009. Pengolahan Sampah Terpadu. Yogyakarta : Kanisius

Latar Muhammad Arief. 2016. Pengolahan Limbah Industri Dasar Dasar Pengetahuan dan Aplikasi di Tempat Kerja. Yogyakarta : ANDI

Lidyasanty, dkk. 2016. Pengelolaan Limbah Kotoran Ternak Dalam Upaya Pencegahan Pencemaran Lingkungan Di Kota Kotamobagu. Jurnal Zootek (“Zootek” Journal) Vol: 36 No.1 : Hal 226-237. (Online). http://ejournal.unsrat.ac.id. Diakses 13 Desember 2017.

Mundiatun dan Daryanto. 2015. Pengelolaan Kesehatan Lingkungan. Yogyakarta : Gava Media. 
Jurnal Sulolipu : Media Komunikasi Sivitas Akademika dan Masyarakat

Vol. 18 No 22018

e-issn : 2622-6960, p-issn : 0854-624X

Republik Indonesia. 2016. Permenkes No 70 Tahun 2016 Tentang Standar Dan Persyaratan Kesehatan Lingkungan Kerja Industri.

Republik Indonesia. 2017. Permenkes No 50 Tahun 2017 Tentang Standar Baku Mutu Kesehatan Lingkungan dan Persyaratan Kesehatan untuk Vektor dan Binatang Pembawa Penyakit serta Pengendaliannya.

Republik Indonesia. 2010. Permentan No 13 Tahun 2010 Tentang Persyaratan Rumah Potong Hewan Ruminansia dan Unit Penangana Daging (Meat Cutting Plant).

Riduwan. 2015. Dasar Dasar Statistika. Bandung : Alfabeta.

Singgih H Sigit dan Upik Kusumawati. 2006. Hama Permukiman Indonesia Pengenalan,Biologi dan Pengendalian. Bogor: UKPHP IPB.

Sugiyono. 2015. Metode Penelitian Kombinasi. Bandung : Alfabeta.

Suryatri Darmiatun dan Tasrial. 2015. Prinsip Prinsip K3LH Keselamatan dan Kesehatan Kerja dan Lingkungan Hidup. Malang : Gunung Samudra.

Perdana Ginting. 2008. Sistem Pengelolaan Lingkungan dan Limbah Industri. Bandung : Yrama Widia.

Wikipedia. 2013. Lalat kandang. (Online). https://ms.wikipedia.org/wiki/Lalat_kandang. Diakses 28 Januari 2018

Wikipedia. 2017. Lalat Daging. (Online). https://id.wikipedia.org/wiki/Lalat_Daging. Diakses 28 Januari 2018

Zufra Inayah, dkk. 2014. Perbedaan Kepadatan Lalat Yang Hinggap Pada Fly Grill Yang Berbeda Warna Di Pasar Srimangunan. Dosen Prodi kesehatan Masyarakat STIKES Insan Unggul Surabaya Volume 4 (1) : 1-10. (Online). http://ejurnal.stikes-insam-unggul.ac.id. Diakses 23 Desember 2017. 